\title{
ESTIMATION OF SOME HEAVY METALS RESIDUES IN BLOOD SERUM AND TISSUES OF CAMELS
}

\author{
SANAA, A. ABDOU*; FATMA, F. MOHAMED ${ }^{* *}$ and EMAN, F. MOHAMED ${ }^{* * *}$ \\ *Animal Health Research Institute (Prov. Labs., Banha branch, Biochemistry Dept. \\ ***Animal Health Research Institute Shebin El kom Provincial Lab. Biochemistry Dept. \\ *** Animal Health Research Institute Prov. Labs., Shebin El kom branch, Food Hygienic Dept.
}

Email: drsanaa22@yahoo.com

Assiut University web-site: www.aun.edu.eg

\begin{abstract}
Received at: 12/3/2015

Accepted: 10/4/2015

A total of 75 samples of serum, muscles, lungs, livers and kidneys of slaughtered camels (15 of each) were collected from Banha abattoir in Kalubia Governorate and they were analyzed for the presence of heavy metals (Lead, Cadmium, Copper and Zinc) by using Atomic Absorption Spectrophotometer. The obtained results indicated that the mean values of Lead concentrations in the examined samples of serum, muscle, lung, liver and kidney were $0.014 \mu \mathrm{g} / \mathrm{ml}, 0.107,0.81,0.66$ and 0.57 $\mathrm{mg} / \mathrm{kg}$ wet weight respectively. Results showed that mean concentrations of lead in lungs and livers were significantly higher $(\mathrm{p} \leq 0.05)$ than that reported in kidneys and muscles. However, the mean values of Cadmium concentrations in the examined samples of serum, muscle, lung, liver and kidney were $0.007 \mu \mathrm{g} / \mathrm{ml}, 0.07,0.39,0.52$ and $1.28 \mathrm{mg} / \mathrm{kg}$ wet weight respectively. Significant differences $(\mathrm{p} \leq 0.05)$ in the mean concentrations of cadmium were recorded between the studied tissues as the highest mean concentration was reported in the kidneys, then in the livers, while the muscles contained the minimum mean concentration. Meanwhile, the mean values of Copper concentrations in the examined samples of serum, muscle, lung, liver and kidney were $1.29 \mu \mathrm{g} / \mathrm{ml}, 1.37,2.75,3.94$ and $3.25 \mathrm{mg} / \mathrm{kg}$ wet weight respectively. Significant differences $(\mathrm{p} \leq 0.05)$ in the mean concentrations of Copper were recorded between the studied tissues as the highest mean concentration was reported in the liver. Whereas, the mean values of Zinc concentrations in the examined samples of serum , muscle, lung, liver and kidney were $1.96 \mu \mathrm{g} / \mathrm{ml}, 16.94,10.68,22.22$ and $8.43 \mathrm{mg} / \mathrm{kg}$ wet weight respectively. Significant differences $(\mathrm{p} \leq 0.05)$ in the mean concentrations of Zinc were recorded between the studied tissues as the highest mean concentration was reported in the liver and muscles. All examined heavy metals were within the normal level in serum. Generally, lungs, livers and kidneys were found to have the highest significant levels of $\mathrm{Pb}$ and $\mathrm{Cd}$ and muscles the lowest levels.
\end{abstract}

Key words: Heavy metals, Residues in blood serum, Tissues, Camels.

\section{INTRODUCTION}

Pollution of the environment with heavy metals is a serious problem in most countries of the world. Industrial evolution, the intense use of raw materials, and agricultural technology lead to polluting of natural environment. Also, air pollution of local and distant origin may contribute to the metals load of natural terrestrial ecosystems. (Abou Arab et al., 2012).

These elements are accumulated in soils and plants when animals are fed with these plants, high levels of these elements accumulate in their bodies, some heavy metals (copper and zinc) are essential for growth and development of plant and animals, others (lead and cadmium) are toxic even in trace amounts. One of a main source of heavy metals for human is meat. Meat is a very essential source of protein for healthy growth of people.

Dromedaries (camels) are of great important in the Arab and African world. In these countries .Where the meat of camel play an important role as source of protein. (El Bahri et al.,1999).

Meat is an important source of a wide range of essential trace metals for humans, but may also carry toxic metals as residues, Contamination with heavy metals is a serious threats, not only because of their 
toxicity but also because of bioaccumulation in the food chain (Demirezen and Uruc, 2006). Kidney and liver are the tissues and organs that have a propinquity to bioaccumulate toxic metals as $\mathrm{Cd}$ and $\mathrm{Pb}$. The residues measured in these animal organs may also indicate the degree of pollution of the grazing area and drinking water (Mokgalaka et al., 2008 and Sedki et al., 2003). These organs can also serve as a rich source of essential microelements (notably $\mathrm{Fe}, \mathrm{Cu}, \mathrm{Zn}$ and $\mathrm{Se}$ ) in the human diet (Nriagu et al., 2009). Kidney, liver and lung are low in cost and are a component of some traditional Egyptian diets, thus toxic residues can affect those with low incomes who may not have access to medical care.

Serious health problems can develop as a result of excessive accumulation of these metals in the human body through dietary intake (Oliver, 2007). Although some metals such as $\mathrm{Zn}$ and $\mathrm{Cu}$ are essential at low concentrations, their excessive concentrations in food are of great concern because of their toxicity to humans and animals at relatively higher concentrations (Akotol et al., 2014, Kabata- Pendias and Mukherjee 2007). $\mathrm{Pb}$ and $\mathrm{Cd}$ are considered potential carcinogens and are associated with etiology of a number of diseases especially cardiovascular, kidney, nervous system, blood as well as bone diseases (Järup, 2003).

The aim of the present study was to investigate the levels of lead, cadmium, copper and zinc in serum, meat, lung, liver and kidney of camel slaughtered in Benha abattoir at Kalubia Governorate in order to detect their possible toxic levels on human health.

\section{MATERIALS and METHODS}

Animals: 15 healthy male camels (Camels dromedaries) from local breed with mean age of 5-7 years were used in this study.

Serum samples: Before slaughtering, blood samples were collected from jagular vein using vacutainer tubes without heparin. Serum were collected by centrifugation for $3000 \mathrm{rpm} / 15 \mathrm{~min}$ and packed in Eppendorf tubes, and then stored at $-20{ }^{\circ} \mathrm{C}$ until subsequent analysis.

Tissue samples: The animals were slaughtered in Banha abattoir at Kalubia Governorate and samples of muscle, lung, liver and kidney were taken from each camels for determination of the mineral elements. Samples were frozen prior to shipment to the laboratory.

Determination of heavy metals and trace elements: 1.1. Washing procedure (Lopez et al. 2000):

The test tubes, polyethylene tubes and glassware were soaked in water and soap for 2 hours then rinsed several times with tap water. Moreover, the glassware was rinsed once with distilled water, once with cleaning mixture $(520 \mathrm{ml}$ deionized water, $200 \mathrm{ml}$ concentrated HCL and $80 \mathrm{ml} \mathrm{H} 2 \mathrm{O} 2$ ) and once with washing acid (10\% HNO3). Finally, they were washed with deionized water and then air-dried in incubator away from contamination or dust.

\subsection{Digestion procedure (Chowdhury et al., 2005 and Miranda et al., 2005):}

One gram of each sample ( $1 \mathrm{ml}$ serum) was processed by a sharp scalpel in a screw capped tube and $5 \mathrm{ml}$ of the digestion mixture $(60 \mathrm{ml}$ nitric acid " $60 \%$ " and 40 $\mathrm{ml}$ perchloric acid"70 \%") were added. The tubes were tightly closed and the contents were vigorously shaken and allowed to stand overnight. Further, the tubes were heated for 3 hours in water bath at $70^{\circ} \mathrm{C}$ to ensure complete digestion of the samples. The digestion tubes were vigorously shaken at 20 minutes intervals during the heating period. Therefore, the tubes were cooled at room temperature and then diluted with $5 \mathrm{ml}$ deionized water and filtered through Wattman filter paper No 42. The filtrate was collected in polyethylene tubes and kept at room temperature until analysis.

\subsection{Preparation of blank and standard solutions} (Rahimi and Rokni, 2008):

Blanks and standard solutions were prepared in the same manner as for wet digestion and by using the same chemicals. Blank tubes were used to determine the contamination that may be present in the chemicals used for wet digestion. While, serial standard solutions were prepared for the element by using pure certified metal standard at ideal adequate strength.

\section{Determination:}

Instrumental procedures for various analyses of heavy metals were based on those suggested in the operator manual of the flame Atomic Absorption Spectrophotometer (UNICAM969AA Spectronic, USA). Accurately, the apparatus was adjusted at wave lengths of $217.0 \mathrm{~nm}$ for lead and $228.8 \mathrm{~nm}$ for cadmium, for $324.8 \mathrm{~nm}$ copper and $346.7 \mathrm{~nm}$ for zinc. Absorbance and concentration of the metal were recorded on the digital scale of the apparatus. The obtained results of such metal levels in the examined samples were calculated as $\mathrm{mg} / \mathrm{kg}$ on wet, and $\mu \mathrm{g} / \mathrm{ml}$ for serum.

\section{Stastistical analysis:}

Data collected were presented as mean and standard error and were subjected to one way analysis of variance (ANOVA) $\mathrm{P} \leq 0.05$ to assess wither each heavy metal varied significantly between serum and tissues of camel. All statistical calculations were performed with SPSS Inc (Version17.0 for Windows) (Ozdamar, 1991). 


\section{RESULTS}

The obtained results in this study are summarized in table 1,2 .

Table 1: Mean values of heavy metal concentrations of serum $(\mu \mathrm{g} / \mathrm{ml})$, muscle and organs $(\mathrm{mg} / \mathrm{kg})$ of camels.

\begin{tabular}{|c|c|c|c|c|c|c|}
\hline \multirow[t]{2}{*}{ Meatls } & & \multirow{2}{*}{$\begin{array}{l}\text { Serum } \\
\mu \mathrm{g} / \mathrm{ml}\end{array}$} & \multicolumn{4}{|c|}{ Different organs } \\
\hline & & & muscle & lung & liver & kidney \\
\hline \multirow[t]{3}{*}{$\begin{array}{c}\text { Lead } \\
\mathrm{Pb}(\mathrm{mg} / \mathrm{kg})\end{array}$} & Min. - Max. & ND-0.02 & ND-0.27 & ND-1.46 & ND-1.18 & ND- 0.97 \\
\hline & mean \pm SE & $0.014 \mathrm{~b} \pm 0.004$ & $0.11 \mathrm{~b} \pm 0.06$ & $0.81 \mathrm{a} \pm 0.15$ & $0.66 \mathrm{a} \pm 0.13$ & $0.57 \mathrm{a} \pm 0.13$ \\
\hline & ${ }^{1} \mathrm{MPL}(\mathrm{ppm})$ & - & 0.1 & 0.5 & 0.5 & 0.5 \\
\hline \multirow[t]{3}{*}{$\begin{array}{c}\text { Cadmium } \\
\mathrm{Cd}(\mathrm{mg} / \mathrm{kg})\end{array}$} & Min. - Max. & ND-0.01 & ND-0.16 & ND-0.7 & ND-0.89 & ND-2.01 \\
\hline & mean \pm SE & $0.007 \mathrm{c} \pm 0.003$ & $0.07 \mathrm{bc} \pm 0.045$ & 0.39 bc \pm 0.12 & $0.52 \mathrm{~b} \pm 0.11$ & $1.28 \mathrm{a} \pm 0.22$ \\
\hline & ${ }^{1} \mathrm{MPL}(\mathrm{ppm})$ & - & 0.05 & 0.5 & 0.5 & 1 \\
\hline \multirow[t]{3}{*}{$\begin{array}{c}\text { Copper } \\
\mathrm{Cu}(\mathrm{mg} / \mathrm{kg}) \\
\end{array}$} & Min. - Max. & $0.19-2.99$ & $0.65-2.11$ & $01.3-4.16$ & $1.86-5.53$ & $1.42-5.10$ \\
\hline & mean \pm SE & $1.29 \mathrm{c} \pm 0.31$ & $1.37 \mathrm{c} \pm 0.16$ & $2.75 \mathrm{~b} \pm 0.28$ & $3.94 \mathrm{a} \pm 0.43$ & $3.25 \mathrm{ab} \pm 0.41$ \\
\hline & ${ }^{2} \mathrm{MPL}(\mathrm{ppm})$ & - & 20 & 20 & 20 & 20 \\
\hline \multirow{3}{*}{$\begin{array}{c}\text { Zinc } \\
\mathrm{Zn}(\mathrm{mg} / \mathrm{kg})\end{array}$} & Min. - Max. & $0.41-3.85$ & $6.21-30.65$ & $2.43-21.87$ & $10.15-39.98$ & $1.96-18.33$ \\
\hline & mean \pm SE & $1.96 \mathrm{~d} \pm 0.37$ & $16.94 \mathrm{ab} \pm 2.63$ & $10.68 \mathrm{bc} \pm 1.96$ & $22.22 \mathrm{a} \pm 3.20$ & $8.43 \mathrm{c} \pm 1.77$ \\
\hline & ${ }^{3} \mathrm{MPL}(\mathrm{ppm})$ & - & 50 & 50 & 50 & 50 \\
\hline
\end{tabular}

${ }^{1}$ MPL: Maximum Permissible Limit stipulated by E.O.S (2010)

${ }^{2}$ MPL: Maximum Permissible Limit of Food Stuffs Cosmetics and Disinfectant Act (2002)

${ }^{3}$ MPL: Maximum Permissible Limit stipulated by FAO/WHO (2000)

S.E $=$ Standard error of mean $\quad$ ND: non detectable

a-b Mean values withen the same raw with different superscript letters are statistically different at $\mathrm{P} \leq 0.05$

Table 2: Acceptability of examined samples $(n=15)$ of camels meat and organs based on their concentrations of heavy metals according to E.O.S (2010), FAO/WHO (2000) and Food Stuffs Cosmetics and Disinfectant Act (2002).

\begin{tabular}{|c|c|c|c|c|c|c|}
\hline \multirow{2}{*}{$\begin{array}{l}\text { samples } \\
\text { muscle }\end{array}$} & \multicolumn{2}{|c|}{ Acceptability } & \multirow{2}{*}{$\frac{\text { Lead }}{9}$} & \multirow{2}{*}{$\frac{\text { Cadmium }}{10}$} & \multirow{2}{*}{$\begin{array}{c}\text { Copper } \\
-\end{array}$} & \multirow{2}{*}{$\frac{\text { Zinc }}{-}$} \\
\hline & ND & $\mathrm{NO}$ & & & & \\
\hline & & $\%$ & 60 & 66.67 & - & - \\
\hline & WPL & $\mathrm{NO}$ & 5 & 4 & 15 & 15 \\
\hline & & $\%$ & 33.33 & 26.66 & 100 & 100 \\
\hline & OPL & $\mathrm{NO}$ & 1 & 1 & - & - \\
\hline & & $\%$ & 6.67 & 6.67 & - & - \\
\hline \multirow[t]{6}{*}{ lung } & ND & $\mathrm{NO}$ & 4 & 8 & - & - \\
\hline & & $\%$ & 26.67 & 53.33 & - & - \\
\hline & WPL & $\overline{\mathrm{NO}}$ & 4 & 4 & 15 & 15 \\
\hline & & $\%$ & 26.67 & 26.67 & 100 & 100 \\
\hline & OPL & $\mathrm{NO}$ & 7 & 3 & - & - \\
\hline & & $\%$ & 46.66 & 20 & - & - \\
\hline \multirow[t]{6}{*}{ liver } & ND & $\mathrm{NO}$ & 6 & 6 & - & - \\
\hline & & $\%$ & 40 & 40 & - & - \\
\hline & WPL & $\mathrm{NO}$ & 4 & 5 & 15 & 15 \\
\hline & & $\%$ & 26.67 & 33.33 & 100 & 100 \\
\hline & $\overline{\mathrm{OPL}}$ & $\mathrm{NO}$ & 5 & 4 & - & - \\
\hline & & $\%$ & 33.33 & 26.67 & - & - \\
\hline \multirow[t]{6}{*}{ kidney } & ND & $\mathrm{NO}$ & 6 & 6 & - & - \\
\hline & & $\%$ & 40 & 40 & - & - \\
\hline & WPL & $\mathrm{NO}$ & 5 & 4 & 15 & 15 \\
\hline & & $\%$ & 33.33 & 26.67 & 100 & 100 \\
\hline & OPL & $\mathrm{NO}$ & 4 & 5 & - & - \\
\hline & & $\%$ & 26.67 & 33.33 & - & - \\
\hline
\end{tabular}

ND: Non detected value. WPL: Withen permissible Limits.

OPL: Over permissible Limits.

E.O.S. (2010): $0.1 \mathrm{ppm}$ for muscles and $0.5 \mathrm{ppm}$ for lung, liver and kidney for Lead . $1 \mathrm{ppm}$ for kidney and $0.5 \mathrm{ppm}$ for muscles, lung and liver for Cadmium.

Food Stuffs Cosmetics and Disinfectant Act (2002): 20 ppm for Cupper.

FAO/WHO (2000): 50 ppm for Zinc 


\section{DISCUSSION}

Heavy metals ranged between toxic or essential elements, their toxicities varies between CNS- disturbances, hepato-, nephro-, immunotoxicties or reproduction dysfunctions. In addition their long term toxicities may be induce mutagenicity or carcinogenicity such as Lead, Cadmium, but the essential elements needed for feed requirements by recommended levels over dose may cause also toxicities such as Iron, Copper, Zinc. (Klassen et al., 1986)

Table 3: Data on metal levels in camel serum and tissues from different region of world.

\begin{tabular}{|c|c|c|c|c|c|c|c|}
\hline Study/country & Animal & organ & $\mathbf{P b}$ & Cd & $\mathbf{C u}$ & $\mathbf{Z n}$ & units \\
\hline \multirow{5}{*}{ Sharkawy et al. 2002 Egypt } & Camel & serum & 0.15 & 0.23 & 1.95 & 14.5 & $\mathrm{ppm}$ \\
\hline & $<6$ year & Muscle & 0.06 & 0.25 & 6.11 & 31.32 & \\
\hline & & Lung & 2.64 & 0.29 & 8.32 & 24.07 & \\
\hline & & Liver & 2.85 & 0.36 & 54.52 & 29.64 & \\
\hline & & Kidney & 8.13 & 0.40 & 6.86 & 23.33 & \\
\hline \multirow{4}{*}{$\begin{array}{c}\text { Abdel Basset } \text { et al. } \mathbf{2 0 1 4} \\
\text { Morocco }\end{array}$} & camel & Liver & 1.33 & 0.25 & 14.77 & 10.88 & $\mathrm{mg} / \mathrm{kg}$ \\
\hline & & Lung & 0.86 & 0.023 & 1.65 & 4.05 & \\
\hline & & Muscle & 0.71 & 0.12 & 1.10 & 9.48 & \\
\hline & & Kidney & 0.96 & 0.69 & 1.45 & 4.17 & \\
\hline Abdelrahman et al. 2013 Saudia & camel & serum & & & 57.5 & 76 & $\mu \mathrm{g} / \mathrm{dl}$ \\
\hline \multirow[t]{3}{*}{ Arabia } & & Liver & & & 16.2 & 89.89 & $\mathrm{ppm}$ \\
\hline & & Kidney & & & 4.2 & 20.56 & \\
\hline & & $\begin{array}{c}\text { fresh } \\
\text { muscle }\end{array}$ & & & 1.67 & 45.68 & \\
\hline $\begin{array}{c}\text { Alturiqi and Albedair } 2012 \\
\text { Saudia Arabia } \\
\end{array}$ & camel & muscle & 5.48 & 1.07 & 1.33 & 16.74 & $\mu \mathrm{g} / \mathrm{g}$ \\
\hline Al Busadah 2003 & camel & serum & & & 113.5 & 103.4 & $\mu \mathrm{g} / \mathrm{dl} \mathrm{mg/kg}$ \\
\hline Saudia Arabia & & Liver & & & 265.1 & 148.7 & \\
\hline $\begin{array}{c}\text { Badis et al. } 2014 \\
\text { Algeria }\end{array}$ & camel & muscle & 2.01 & 0.08 & & & $\mu \mathrm{g} / \mathrm{g}$ \\
\hline $\begin{array}{c}\text { Jalal } \text { et al. } 2010 \\
\text { Saudia Arabia }\end{array}$ & camel & serum & 3.73 & 0.91 & 2.82 & 23.51 & ppm \\
\hline $\begin{array}{c}\text { Elrayah } \text { et al. } 2014 \\
\text { Sudan }\end{array}$ & camel & serum & & & 0.20 & 0.22 & $\mu \mathrm{g} / \mathrm{ml}$ \\
\hline
\end{tabular}

\section{Lead $(\mathbf{P b})$}

In the present study, the mean detectable concentrations of lead $(\mathrm{Pb})$ levels in examined serum, muscle, lung, liver and kidney samples of camel were; $0.014 \mu \mathrm{g} / \mathrm{ml}, 0.107 \mathrm{mg} / \mathrm{kg}, 0.81 \mathrm{mg} / \mathrm{kg}, 0.66$ $\mathrm{mg} / \mathrm{kg}$ and $0.57 \mathrm{mg} / \mathrm{kg}$ respectively. (Table 1 ). These differences in Lead concentrations in the examined samples of blood serum, fresh meat and edible offals were significant different $(p \leq 0.05)$.

Lead was accumulated mainly in camel's lung, liver and kidney samples. The highest concentration of this metal was observed in lung $0.81 \mathrm{mg} / \mathrm{kg}$ while the lowest concentrations was observed in muscle 0.11 $\mathrm{mg} / \mathrm{kg}$. It shows that $\mathrm{Pb}$ get into the body through breathing. Air born sources like industrial emission and combustion of fuel having $\mathrm{Pb}$ additives may affect grazing animals, (Mehmood et al., 2014). According to the safe permissible limit stipulated by E.O.S. (2010) for lead in. fresh meat $0.1 \mathrm{mg} / \mathrm{kg}$, and $0.5 \mathrm{mg} / \mathrm{kg}$ for offals, it was indicated that $6.67 \%$, $46.66 \%, 33.33 \%$ and $26.67 \%$ of the examined fresh samples of muscles, lung, liver and kidneys respectively, were not in accordance with this limit (Table, 2). When compared to results of similar studies from other countries. This higher trend was supported by the result of Abdel Basset et al. (2014) that indicated higher $\mathrm{Pb}$ concentrations as $1.33 \mathrm{mg} / \mathrm{kg}$ in liver, $0.86 \mathrm{mg} / \mathrm{kg}$ in lung and $0.69 \mathrm{mg} / \mathrm{kg}$ in kidneys of camel in Morocco. Much higher levels as $2.64 \mathrm{ppm}, 2.85 \mathrm{ppm}$ and $8.13 \mathrm{ppm}$ of $\mathrm{Pb}$ in lung, liver and kidney of camel respectively has been recorded by Sharkawy et al. (2002) in Assuit abattoir (Egypt).

Lead content of camel muscle were $0.11 \mathrm{mg} / \mathrm{kg}$ and this is lower than that obtained by Abdel Basset $e t a l$. (2014) who reportd mean lead concentrations of 0.71 $\mathrm{mg} / \mathrm{kg}$ for muscles. And also lower than those recorded by Badis et al.( 2014) who detected mean lead concentrations of $2.01 \mathrm{ppm}$ in Algeria, While, it is higher than that reported by Sharkawy et al. (2002) as $0.06 \mathrm{ppm}$. The level of heavy metals in meat from different animals depends on factors such as environmental conditions, type of pasture and industrialization development. (Kadim et al.; 2013). Regarding to Lead level in serum $(0.014 \mu \mathrm{g} / \mathrm{ml})$ and 
this is lower than that recorded by Sharkawy et al. (2002) as $0.15 \mathrm{ppm}$. Also, higher results (3.73 ppm) recorded by Jalal et al. (2010) in camel serum from Saudia Arabia. (Table, 3).

Low blood $\mathrm{Pb}$ levels can influence neurobehavioral performance in children and may be a contributor to Attention - Deficit /Hyperactivity Disorder (ADHD) (Kwaansa et al., 2012). Lead toxicity can cause colic, constipation and anemia. It may also induce increased blood pressure, cardiovascular disease, liver dysfunction, renal damage and peripheral neuropathy in adults. Foetal neuro-developmental effects and reduced learning capacity in children are among the most serious effects of lead toxicity (Bolger et al., 2000). An increase in the maternal blood lead level may contribute to reducing gestational duration and birth weight. Also lead is immunotoxic and classified as a $2 \mathrm{~B}$ carcinogen by the International Agency for Research on Cancer (IARC) (Goyer and Clarkson, 2001).

\section{Cadmium (Cd)}

The mean detectable concentrations of Cadmium (Cd) levels in examined serum, muscle, lung, liver and kidney samples of camel were ; $0.007 \mu \mathrm{g} / \mathrm{ml}, 0.07$ $\mathrm{mg} / \mathrm{kg}, \quad 0.39 \mathrm{mg} / \mathrm{kg}, 0.52 \mathrm{mg} / \mathrm{kg}$ and $1.28 \mathrm{mg} / \mathrm{kg}$ respectively (Table, 1).

The highest $\mathrm{Cd}$ concentration was observed in the kidneys of camel $(1.28 \mathrm{mg} / \mathrm{kg})$. and this is in line with the suggestion that the kidney is the main storage organ in animals subjected to chronic low-levels of cadmium exposure García-Fernández et al. (1996). The excretory mechanism for such metal, which is based on low molecular compounds with - $\mathrm{SH}$ groups, was poorly developed in vertebrates and could not cope with high levels of such metal contaminations (Pompe-Gotal and Crnic, 2002).

According to the legal standard $(0.05 \mathrm{mg} / \mathrm{kg})$ in meat, (0.5) $\mathrm{mg} / \mathrm{kg}$ in offals except kidney $(1 \mathrm{mg} / \mathrm{kg})$ recommended by E.O.S. (2010) $33.33 \%$ of kidney, $26.67 \%$ of liver, $20 \%$ of lung and $6.67 \%$ of muscle exceeded the permissible limits for Cadmium. (Table, $3)$.

The results of the present study were higher than those noticed by Sharkawy et al. (2002) who recorded (0.40 ppm) in kidneys, (0.36 ppm) in liver and (0.29 ppm) in lungs of camel in Egypt. Also, Abdel Basset et al. (2014) reported this low trend of $\mathrm{Cd}$ accumulation in kidneys $(0.69 \mathrm{mg} / \mathrm{kg})$, in liver $(0.25$ $\mathrm{mg} / \mathrm{kg})$ and in lung $(0.023 \mathrm{mg} / \mathrm{kg})$ of camel in Morocco. Cadmium content of camel muscle were $0.07 \mathrm{mg} / \mathrm{kg}$ and this is in agreement with that obtained by Badis et al. (2014) who estimated $0.08 \mathrm{ppm}$ in camel fresh meat from Algeria and lower than that obtained by Abdel Basset et al. (2014) who detected that the concentration of $\mathrm{Cd}$ were $0.12 \mathrm{mg} / \mathrm{kg}$ in muscle of camel in Morocco. Also, lower than those found by Alturiqi and Albedair (2012) in Saudia Arabia, who reported that camel meat contained 1.07 $\mu \mathrm{g} / \mathrm{g}$ of Cadmium. The mean value of Cadmium level in serum of camel $(0.007 \mu \mathrm{g} / \mathrm{ml})$ is lower than results obtained by Sharkawy et al. (2002) who detected 0.15 ppm of Cd residue in camel serum from Egypt. Also, Jalal et al. (2010) recorded high levels of Cd (0.91 ppm) in camel serum from Saudia Arabia. (Table, 3).

Vos et al. (1987) stated that Cd may accumulate in the human body and may induce kidney dysfunction, skeletal damage and reproductive deficiencies.

\section{Copper $(\mathbf{C u})$}

The mean detectable concentrations of Copper $(\mathrm{Cu})$ levels in examined serum, muscle, lung, liver and kidney samples of camel were; $1.29 \mu \mathrm{g} / \mathrm{ml}, 1.37$ $\mathrm{mg} / \mathrm{kg}, 2.75 \mathrm{mg} / \mathrm{kg}, 3.94 \mathrm{mg} / \mathrm{kg}$ and $3.25 \mathrm{mg} / \mathrm{kg}$ respectively (Table, 1). Moreover, Table, 2 showed that all examined samples of serum, muscle, lung, liver and kidney of camel were accepted based on their copper content according to Food Stuffs Cosmetics and Disinfectant Act (2002) which stated that copper should not exceed $20 \mathrm{mg} / \mathrm{kg}$ in fresh meat and offals.

Table, 3 revealed that Copper was detectable in all the samples but was highest in the liver with a mean concentration of $3.94 \mathrm{mgkg}$. The ranges of hepatic $\mathrm{Cu}$ in different countries were reported to be as follows: $54.52 \mathrm{ppm}$ in Egypt (Sharkawy et al. 2002), 16.2 $\mathrm{mg} / \mathrm{kg}$ in Morocco (Abdel Basset et al. 2014) and $265.1 \mathrm{mg} / \mathrm{kg}$ Saudia Arabia (Al Busadah 2003). Our results were similar to those obtained by Alturiqi and Albedair (2012) and Abdel Basset et al. (2014) who recorded that the concentrations of $\mathrm{Cu}$ in muscle of camel were $1.33 \mu \mathrm{g} / \mathrm{g}, 1.10 \mathrm{mg} / \mathrm{kg}$ respectively. While, higher concentrations of $\mathrm{Cu}(6.11 \mathrm{ppm})$ in muscle were recorded by Sharkawy et al. (2002).

Meanwhile, The results from this study were higher than those reported in the lung $(1.65 \mathrm{mg} / \mathrm{kg})$, Muscle $(1.10 \mathrm{mg} / \mathrm{kg})$ and kidney $(1.45 \mathrm{mg} / \mathrm{kg})$ by Abdel Basset et al. (2014) in Morocco. In contrast, higher levels of Copper $8.32 \mathrm{ppm}$ and $6.86 \mathrm{ppm}$ in Lung and kidney of camel respectively was reported by Sharkawy et al. (2002) in Egypt. The mean value of Copper level in serum of camel $(1.29 \mu \mathrm{g} / \mathrm{ml})$ is lower than results obtained by Sharkawy et al. (2002) who detected $1.95 \mathrm{ppm}$ of $\mathrm{Cu}$ residue in camel serum from Egypt. Also, Jalal et al. (2010) recorded high levels of $\mathrm{Cu}(2.82 \mathrm{ppm})$ in camel serum from Saudia Arabia. (Table, 3).

Copper is an essential component of various enzymes and it plays a key role in bone formation, skeletal mineralization and in maintaining the integrity of the connective tissues. Copper is essential for good health, but very high intake can cause health 
problems such as liver and kidney damage (ATSDR, 2004). In humans, 10-30 mg of orally ingested copper from foods stored in copper vessels might cause intestinal discomfort, dizziness and headaches, while excess accumulation of copper in liver may result in hepatitis or cirrhosis and in a hemolytic crisis similar to that seen in acute copper poisoning (Johnson, 1993).

\section{Zinc (Zn)}

Zinc is an essential trace element for animals, being involved in protein synthesis and as a constituent of many metalloenzymes. Consumption of excess $\mathrm{Zn}$ in the diet can result in haematological effects such as anemia and induction of $\mathrm{Cu}$ deficiency by hindering its absorption (ATSDR, 2005).

The mean detectable concentrations of Zinc ( $\mathrm{Zn}$ ) levels in examined serum, muscle, lung, liver and kidney samples of camel were; $1.96 \mu \mathrm{g} / \mathrm{ml}$, $16.94 \mathrm{mg} / \mathrm{kg}, 10.68 \mathrm{mg} / \mathrm{kg}, 22.22 \mathrm{mg} / \mathrm{kg}$ and 8.43 $\mathrm{mg} / \mathrm{kg}$ respectively. in Table 1 . All examined samples of serum, muscle, lung, liver and kidney of camel were accepted based on their Zinc content according to FAO / WHO (2000) which stated that copper should not exceed $50 \mathrm{mg} / \mathrm{kg}$ in fresh meat and offal.

The concentrations of $\mathrm{Zn}(22.22 \mathrm{mg} / \mathrm{kg})$ in the liver were significant higher at $\mathrm{P} \leq 0.05$ compared with those of the muscles, lung and kidney. This high trend of Zinc accumulations in liver have been recorded by Sharkawy et al. (2002) who reported higher concentration 29.64ppm in liver of camel in Egypt; Abdel Basset et al. (2014) who reported $10.88 \mathrm{mg} / \mathrm{kg}$ in Morocco; Abdel Rahman et al. (2013) who reported $89.89 \mathrm{ppm}$ in Saudi Arabia and Al Busadah (2003) who reported $148.7 \mathrm{mg} / \mathrm{kg}$ in Saudi Arabia. Table (3). The results from this study were lower than31.32 ppm, $24.07 \mathrm{ppm}$ and $23.33 \mathrm{ppm}$ reported by Sharkawy et al. (2002) in muscles, lung and kidney respectively. They were also lower than those reported in muscles (45.68 ppm) and (20.56 ppm) kidney by Abdel Rahman et al. (2013). In contrast, our results were higher than that obtained by Abdel Basset et al. (2014) who reported that mean concentrations of $\mathrm{Zn}$ were $9 . .48,4.05,4.17 \mathrm{mg} / \mathrm{kg}$ in muscles, lung and kidney respectively. Blood Zinc levels $(1.96 \mu \mathrm{g} / \mathrm{ml})$ were higher than that recorded by Elrayah et al. (2014) as $0.2296 \mu \mathrm{g} / \mathrm{ml}$ in Sudan. Abdelrahman et al. (2013) also reported $76 \mu \mathrm{g} / \mathrm{dl}$ in Saudia Arabia. In contrast, Jalal et al. (2010) recorded higher levels of $\mathrm{Zn}$ in serum (23.51ppm) of camel from Saudia Arabia, On the other hand, higher levels of $\mathrm{Zn}(14.5 \mathrm{ppm})$ were reported by Sharkawy et al. (2002) in Egypt.

The distribution of copper and zinc among the tissues of animals varies with the age, sex, diet composition and physiological status (Doyle, 1980).
The $\mathrm{Cd} / \mathrm{Zn}$ ratio in the kidney was 0.15 , while it was 0.02 in liver and 0.03 in lung and 0.04 in muscle. Thus, the low zinc concentration in the kidney is attributed to higher cadmium accumulation in that organ. Cadmium causes reductions in both intestinal zinc absorption and hepatic zinc reserves. Smith et al. (1991), Although mechanisms of their interactions are not clearly defined, interactions between toxic and essential metals may disrupt the metabolism of essential metals such as $\mathrm{Zn}$ and $\mathrm{Cu}$. Metallothioneins binds tightly with toxic metals, reducing their availability within cells and therefore reducing their toxic potentials. The synthesis of MT which is induced by the presence of $\mathrm{Cd}$ causes great accumulation of $\mathrm{Zn}$ in the tissues as a result of competition for the cation-binding sites of metallothionein (MT). Cherian and Goyer, (1987) and Goyer (1997).

Heavy metals accumulate in various tissues and are associated with increases in today's biggest killers: Cardiovascular disease and cancer. Reducing these heavy metals from the body has been a challenge to modern day medicine. Metal-mediated formation of free radicals causes various modifications to DNA bases, enhanced lipid peroxidation, and altered calcium and sulfhydryl homeostasis, McDonagh and Sheehan (2008) and Jalal et al. (2010). Lipid peroxides, formed by the attack of radicals on polyunsaturated fatty acid residues of phospholipids, can further react with redox metals finally producing mutagenic and carcinogenic malondialdehy 4hydroxynonenal and other exocyclic DNA adducts (etheno and/or propanoadducts), Bartsch and Nair (2002). Whilst iron (Fe), copper $(\mathrm{Cu})$, chromium $(\mathrm{Cr})$, vanadium $(\mathrm{V})$ andcobalt $(\mathrm{Co})$ undergo redox-cycling reactions, for a second group of metals, mercury $(\mathrm{Hg})$, cadmium $(\mathrm{Cd})$ and nickel $(\mathrm{Ni})$, the primary route for their toxicity is depletion of glutathione and bonding to sulfhydryl groups of protein FigueiredoPereira et al. (1998) and Kern et al. (2007). However, other mechanisms, involving formation of hydrogen peroxide under physiological conditions, have been proposed Flora et al. (2005) and Liu et al. (2001). The unifying factor indetermining toxicity and carcinogenicity for all these metals is the generation of reactive oxygen and nitrogen species Valavanidis et al. (2005). Common mechanisms involving the Fenton reaction, generation of the superoxide radical and the hydroxyl radical appear to be involved for iron, copper, chromium, vanadium and cobaltprimarily associated with mitochondria, microsomes and peroxisomes, Moriwaki et al. (2008).

\section{CONCLUSION}

The results obtained in this study showed that heavy metals such as $\mathrm{Cd}$ and $\mathrm{Pb}$ are significantly more likely to be found in the kidney, liver and lung of camels even at the lower detection levels than in meat 
(muscle tissue). Thus, the meat of animals grazing in polluted areas with heavy metals can be safe for human consumption. While, provided liver, kidney and lung are discarded, as the toxic metals appear to bioaccumulate in these tissues.

\section{REFERENCES}

Abdel Basset, C.; Rabia, E.; Abdallah, B.; Boubker, N. and Abdel Khalid, E. (2014): Distribution of trace elements and heavy metals in liver, lung, meat, heart and kidney of cattle, sheep, camel and equine slaughtered in Casablanca cityMorocco. International Journal of Scientific and Engineering Research, Volume 5, Issue 2, 294.

Abdelrahman, M.M.; Aljumaah, R.S. and Ayadi, A. (2013): Variation of Copper, Zinc, Manganese and Magnesium in blood serum and tissues of two breeds of Dromedary camels in Saudi Arabia. Asian Journal of Animal and Veterinary Advances. 8(1): 91-99.

Abou-Arab, N.M.; Shehata, F.I. and Abd-Elsamea, M.S. (2012): Determination of Lead and Cadmium levels in some meat products in Cairo Governorate. Egypt J. Agri. Res. 90 (1) 361-371.

Akoto1, O.; Bortey-Sam, N.; Nakayama, S.M.M.; Ikenaka, Y.; Baidool, E.; Yohannes, Y.B.; Mizukawa, H. and Ishizuka, M. (2014): Distribution of Heavy Metals in Organs of Sheep and Goat Reared in Obuasi: A Gold Mining Town in Ghana International Journal of Environmental Science and Toxicology (ISSN: 2315-9927) Vol. 2(4) pp. 81-89.

Al-Busadah, K.A. (2003): Trace elements status in camels, cattles and sheep in Saudi Arabia. Pakistan Journal of Biological Sciences (21), 1856-1859.

Alturiqi, A.S. and Albedair A.A. (2012): Evaluation of some heavy metals in certain fish, meat and meat products in Saudi Arabian markets. Egyptian Journal of Aquatic Research (2012) $38,45-49$.

ATSDR (Agency for Toxic Substances and Disease Registry). (2004): Toxicological profile for copper (CAS 7440-50-8). U.S. Department of Health and Human Services, Atlanta, GA.

ATSDR (Agency for Toxic Substances and Disease Registry). (2005): Toxicological profile for zinc (CAS 7440-66-6). U.S. Department of Health and Human Services, Atlanta, GA.

Badis, B.; Rachid, Z and Esma, B (2014): Levels of Selected Heavy Metals in Fresh Meat from Cattle, Sheep, Chicken and Camel Produced in Algeria. Annual Research and Review in Biology 4(8): 1260-1267.

Bartsch, H. and Nair, J. (2002): Potential Role of Lipid Peroxidation Derived DNA Damagein
Human Colon Carcinogenesis: Studies on Exocyclic Base Adducts As Stable OxidativeStress Markers, Cancer Detect Prev., 26: 308-12.

Bolger, M.; Carrington, C.; Larsen, J.C. and Petersen, B. (2000): Safety evaluation of certain food additives and contaminants: lead. WHO Food Addit. Series. 44: 273-312.

Cherian, MG. and Goyer, RA. (1987): metallothioneins and their role in the metabolism and toxicity of metals. Life Sci; 23(1, 2) pp. 1-9.

Chowdhury, M.; Siddique, Z.; Hossain, S.; Kazi, A.; ahsan, M.; Shamim, A. and zaman, M. (2005): Determination of essential and toxic metals in meats, meat products and eggs by spectrophotometric method. J. Bangladesh Chem. Soc.; 42 (2): 165-172.

Demirezen, D. and Uruç, K. (2006): Comparative study of trace elements in certain fish, meat and meat products. Meat. Sci., 74: 255-260

Doyle, J.J. (1980): "Genetic and nongenetic factors affecting the elemental composition of human and other animal tissues-a review," J. Anim. Sci., vol. 50, no. 6, pp.

“EOS" Egyptian Organization for Standardization and Quality Control (2010): Maximum permissible limits of some pollutants in food. Report No.7136/10 related to commission regulation (EC) NO. 1881/2006, p. 5. 19.

El-Bahri, L.; Souilem, O.; Djegham, M.A. and Belguith, J. (1999): Toxicity and advers reactions to some drugs in dromedary (Camelus dromedarius), Vet. Human Toxicol., 41(1): 35-38.

Elrayah, H.A.; Barri, M.E.S.; Samia, H. Abdelrahman; Naam E.D.; Ishraga, G.I.1.; Khojali S.M.E. and Baragoub A.E. (2014): Assessment of zinc and copper in camels (Camelus dromedarius) using certain biochemical indicators Biochemistry and Biotechnology Research Vol. 2(2), pp. 23-26.

Figueiredo-Pereira, M.E.; Yakushin, S. and Cohen, G. (1998): Disruption of the Intracellular Sulfhydryl Homeostasis by Cadmium-induced Oxidative Stress Leads toProtein Thiolation and Ubiquitination in Neuronal Cells, J. Biol. Chem., 273: 12703-9.

Flora, S.J.; Bhadauria, S.; Pant, S.C. and Dhaked, R.K. (2005): Arsenic Induced Blood and Brain Oxidative Stress and its Response to some Thiol Chelators in Rats, Life Sci., 77: 232437.

FAO $/ W H O$ Food and Agricultural Organization/World Health Organization (2000): Report of Codex Committee on food Additives and Contaminants.Available on www FAO/ drocrep/ meeting/005.

Food Stuff Cosmetics and Disinfectant Act (2002): Copper in foods. ARS Lower Mississippi 
Delta Nutrition Intervention Research Initiative, little Rock, Arkansas 72211, USA.

García-Fernández, A.J.; Sánchez-García, J.A.; Gómez-Zapata, M.; Luna A. (1996): Arch. Environ. Contam. Toxicol. 30, 252.

Goyer, R.A. (1997): Toxic and essential metal interactions. Annu. Rev. Nutr 17: 37- 50.

Goyer, R.A. and T.W. Clarkson (2001): Toxic effects of metals. In: Klaassen, C. D. ed. "Casarett and Doull's Toxicology: The Basic Science of Poisons" 6th ed., McGraw-Hill companies, Inc., USA, pp: 811-868.

Jalal, J.A.; Albuseeda, K.A.; Taha, A.; Aboulnaja, K.K.O. and Mohamed, F.E. (2010): Elucidation of the Determinant Factors Affecting Camels' Health in Some Regions of Saudi Arabia: A Biochemical, Histological, and Toxicological Study. JKAU: Sci., Vol. 22 No. 1, pp: 225-238.

Järup, L. (2003): "Hazards of heavy metal contamination," British Medical Bulletin, 68, 167-82.

Johnson, M.A. (1993): Copper. In: M acrae, R., R.K. Robinson and M.J. Sadler (Eds.), Encyclopaedia of Food Science, Food Technology and Nutrition. Academic Press, London.

Kabata-Pendias, A. and Mukherjee, AB. (2007): Trace elements from soil to human. NewYork: Springer-Verlag.

Kadim, I.; Kadim, I.; Mahgoub, O.; Faye, B. and Farouk, M. (2013): Camel meat and meat products. CAB International publ, Oxfordshire, UK and Boston, USA. 2013; 248.

Kern, J.K.; Grannemann, B.D.; Trivedi, M.H. and Adams, J.B. (2007): SulfhydrylreactiveMetals in Autism, J. Toxicol. Environ. Health A. Apr 15, 70(8): 715-21.

Klassen, C.D.; Amdur, M.O. and Doll, J. (1986): Cassaret and Doll's Toxicology (The basic science of poisons), 3rded. Macmillan Publishing Company, New York, Callier, Macmillan Publishing, London, pp: 598-605.

Kwaansa-Ansa, E.E.; Akoto, J.; Adimado, A.A. and Nam, D. (2012): Determination of Toxic and Essential Elements in Tilapia Species from the Volta Lake with Inductively Coupled Plasma ctrometry. International Journal of Environmental Protection. 2 (7). 30-34.

Liu, S.X.; Athar, M.; Lippai, I.; Waldren, C. and Hei, T.K. (2001): Induction of Oxyradicalsby Arsenic: Implication for Mechanism of Genotoxicity, Proc. Natl. Acad. Sci. USA., 98:1643-8.

Lopez, A; Benedito, J.; Miranda, M.; Hernandez, J. and Shore, R. (2000): Toxic and trace elements in liver, kidney and meat from cattle slaughtered in Galicia (NW Spain). Food Addit. Contam., 17: 447-457.
McDonagh, B. and Sheehan, D. (2008): Effects of Oxidative Stress on Protein Thiols anDisulphides in Mytilus Edulis Revealed by Proteomics: Actin and Protein DisulphideIsomerase are Redox Targets, Mar. Environ. Res., 66: 193-5.

Mehmood, A.; Sarfraz, R.A.; Abdul Qudoos and Akbar, F. (2014): Appraisal of Some Heavy Metals in Organ Meat from Non-industrialized Areas of Faisalabad, Pakistan Global Veterinaria 12 (1): 98-103, 2014

Miranda, M.; López-Alonso, M.; Castillo, C.; Hernádez, J. and Benedito. J. (2005): Effects of moderate pollution on toxic and trace metal level in Calves Spain. J. Environ. From pollouted area of Northen Sci., 131: 543-548.

Mokgalaka, N.S.; Wondimu, T. and Mc Crindle, R.I. (2008): Bull. Chem. Soc. Ethiop., 2008, 22, $1-9$.

Moriwaki, H.; Osborne, M.R. and Phillips, D.H. (2008): Effects of Mixing Metal Lons on Oxidative DNA Damage Mediated by a Fenton-type Reduction, Toxicol In Vitro, 22: $36-44$.

Nriagu, J.; Boughanen, M.; Linder, A.; Howe, A.; Grant, C.; Rattray, Vutchkov M. and Lalor, G. (2009): Ecotoxicol. Environ. Saf. 72, 564-571.

Oliver, MA. (2007): Soil and human health: a review. Eur J Soil Sci; 48, pp. 573-92.

Ozdamar, K. (1991): Biostatistics with SPSS. Kann Pres Eskisehir, pp: 2-23.

Pompe-Gotal, J. and Crnic, AP. (2002): Cadmium in tissue of roe deer (Capreolus capreolus) in Croatia. Vet Arh; 72, pp. 303-310.

Rahimi, E. and Rokni, N. (2008): Measurement of cadmium residues in muscle, liver and kidney of cattle slaughtered in Isfahan abattoir using grafite furnace atomic absorption spectrometry (GFAAS): A preliminary study. Iran. J. Vet. Res., 9: 174-177.

Sedki, N.A.; Lekouch, S.G. and Pineau, A. (2003): Toxic and essential trace metals in muscle, liver and kidney of bovines from a polluted area of Morocco. Sci. Total Environ. 317, 201-205.

Sharkawy, A.A.; Rateb, H.Z. and Abdel-Mohsen, M. (2002): Evaluation of some heavy metals in blood and tissues of male camels as indicator of environmental pollution and its relation to age. Ass. Univ. Bull. Environ. Res. Vol. 5 (1) 73-81.

Smith, R.M.; Leach, R.M.; Muller, L.D.; Griel, L.C. and Baker, D.E.J. (1991): Anim. Sci., 69, 4088.

Valavanidis, A.; Vlahoyianni, T. and Fiotakis, K. (2005): Comparative Study of theFormation of Oxidative Damage Marker 8-hydroxy-2'deoxyguanosine (8-OHdG) Adductfrom the Nucleoside 2'-deoxyguanosine by Transition 
Metals and suspensions of ParticulateMatter in Relation to Metal Content and Redox Reactivity, Free Radic. Res., 39: 1071-81.

Vos, G.; Hovens, JPC. and Delft, WV. (1987): Arsenic, Cadmium, leads and mercury in meat, livers and kidneys of cattle slaughtered in the Netherlands during 1980-1985. Food. Additives and Contaminants.1987; 4: 738.

\section{قياس متبقيات بعض المعادن الثقيله في امصال وانسجه الجمال سناء عبل الرحمن عبده ، فاطمة فتحي محد ، ايمان فتحي محد}

يعتبر تلوث اللحوم و الاحشاء ببعض المعادن الثقيله مثل الرصاص و الكادميوم والنحاس و الزنك ذو الهمية كبيره لما له من الهن اثنار سميه

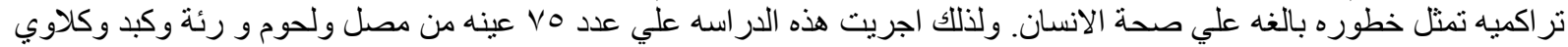

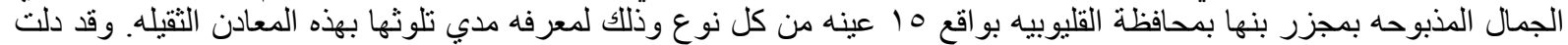

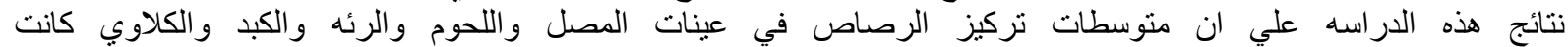

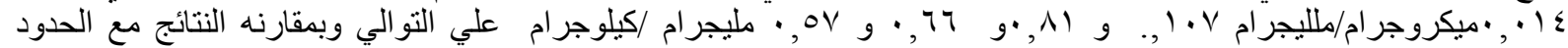

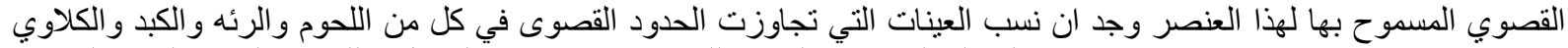

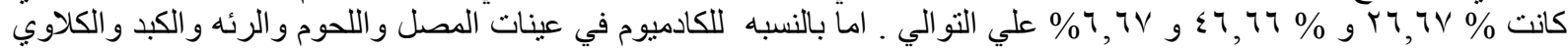

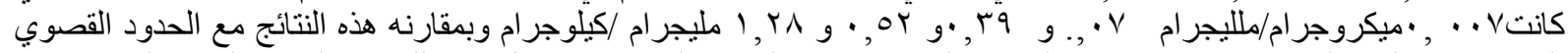

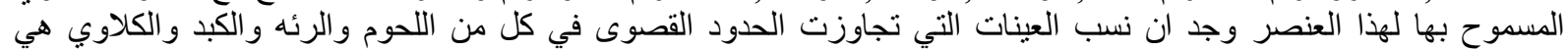

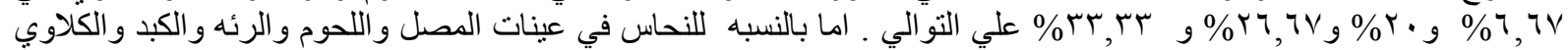

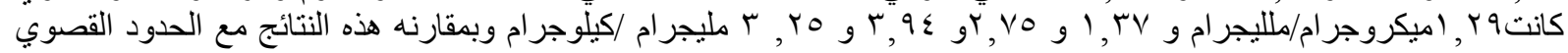

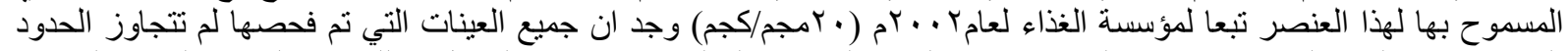

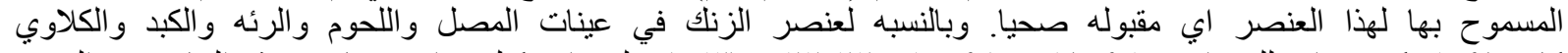

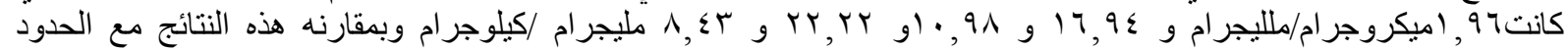

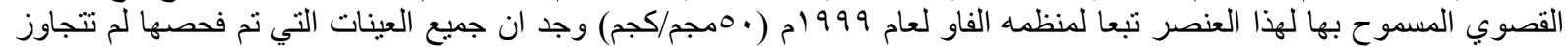

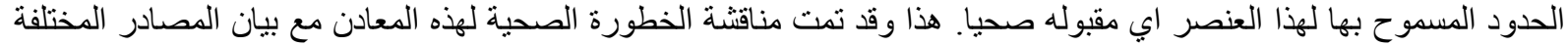
لتلوث لحوم واحشاء الجمال بتلك الملوثات الخطيرة. 